\title{
De geografische inrichting van de rechtspraak
}

\author{
Roland Eshuis*
}

Het onderwerp van dit artikel is de geografische inrichting van de rechtspraak. In Nederland is het aantal plaatsen waar de meest voorkomende rechtszaken worden behandeld in de afgelopen twintig jaar gehalveerd. Na de Herziening van de Gerechtelijke Kaart (HGK) in 2013 presenteerde de Rechtspraak een meerjarenplan dat voorzag in sluiting van nog meer locaties. De storm van kritiek die volgde - niet in laatste plaats vanaf de werkvloer - deed de gerechtsbestuurders op hun schreden terugkeren. Inmiddels is er een duidelijk tegengeluid hoorbaar, een roep om rechtspraak die meer geworteld is in de lokale gemeenschappen, zoals dat bij de Belgische vrederechter het geval is en in de Amerikaanse Community Courts. Het experiment met de Spreekuurrechter in Noord-Nederland inspireerde rechters elders in het land tot vergelijkbare initiatieven, in de vorm van (bijvoorbeeld) wijk- en regelrechters.

Dit artikel behandelt empirische gegevens over de schaalgrootte van de rechtspraak in relatie tot 'toegang tot de rechter'. Het eerste deel van dit artikel beziet de schaalgrootte van de rechtspraak in Europees verband. In hoeverre loopt Nederland in (of uit) de Europese pas? Hoe 'gewoon' is de kleinschaligheid van de Belgische vrederechter? Hoe verdeel je rechtspraaklocaties over het land, en op basis van welke criteria doe je dat? Het tweede deel van het artikel concentreert zich op de Nederlandse situatie: een korte schets van de recente beleidsgeschiedenis en empirische gegevens over de invloed van reisafstand op het gebruik van rechtspraak. De slotparagraaf destilleert uit het voorafgaande een aantal aandachtspunten voor de nieuwe initiatieven om de rechtspraak dichter bij de burger te brengen.

* Dr. R.J.J. Eshuis is als onderzoeker verbonden aan het WODC. 


\section{De schaalgrootte van rechtspraak in internationaal perspectief}

Als eerste stap in deze beschouwing over de schaalgrootte van de rechtspraak nemen we een kijkje in Europa. Hoe grootschalig is de rechtspraak in Nederland? Is die bij de zuiderburen juist kleinschalig? Hoe verhouden die schaalgroottes zich tot de rest van Europa? Alvorens te vergelijken een paar woorden over de criteria op basis waarvan je de schaalgrootte van rechtspraak kunt vergelijken. 'Grootschalig' kan worden begrepen in termen van aantallen behandelde zaken, de grootte van de organisatie (aantal fte's) en de omvang van het verzorgingsgebied van een rechtspraakvoorziening. De omvang van het verzorgingsgebied kun je vergelijken op basis van het aantal personen dat is aangewezen op de betreffende rechtbank, of op basis van de oppervlakte van het geografische gebied waarover de jurisdictie van de rechtbank zich uitstrekt. Daarbij hangen de aantallen zaken, de organisatiegrootte en het aantal inwoners van het verzorgingsgebied nauw samen: meer inwoners betekent meer zaken en daarmee een grotere organisatie. We zullen de vergelijking hier toespitsen op de omvang van het verzorgingsgebied: in oppervlakte, en op basis van het aantal inwoners. Voor Nederland wordt de vergelijking gedaan voor de kantonrechtspraak. Kantonrechters behandelen jaarlijks een miljoen rechtszaken, ongeveer twee derde van het totale volume van rechtszaken in eerste aanleg.

Tabel 1 Zittingslocaties rechtspraak, 'small claims', per land

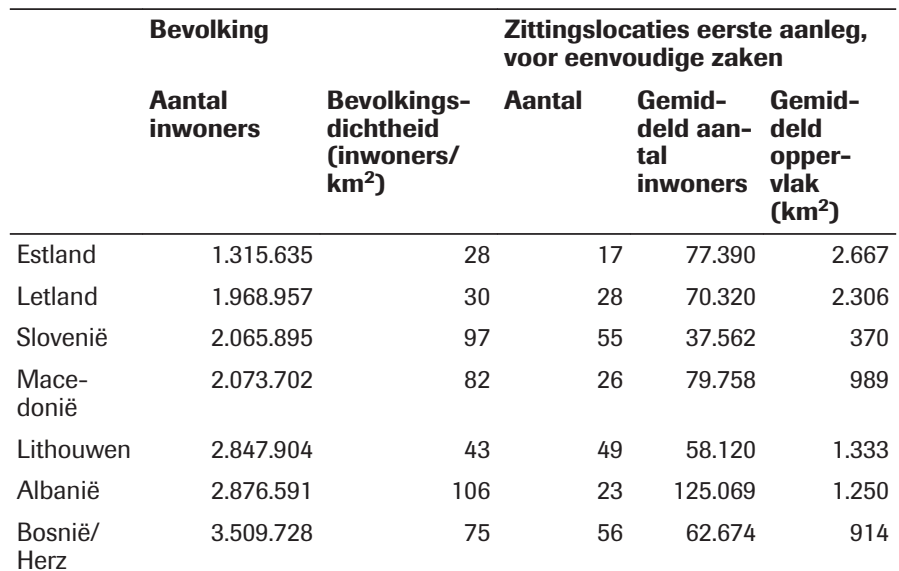


Tabel 1 (Vervolg)

\begin{tabular}{|c|c|c|c|c|c|}
\hline & Bevolking & & $\begin{array}{l}\text { Zittingsloc } \\
\text { voor eenvc }\end{array}$ & $\begin{array}{l}\text { aties eerst } \\
\text { pudige zake }\end{array}$ & $\begin{array}{l}\text { e aanleg, } \\
\text { en }\end{array}$ \\
\hline & $\begin{array}{l}\text { Aantal } \\
\text { inwoners }\end{array}$ & $\begin{array}{l}\text { Bevolkings- } \\
\text { dichtheid } \\
\text { (inwoners/ } \\
\text { km²) }^{2}\end{array}$ & Aantal & $\begin{array}{l}\text { Gemid- } \\
\text { deld aan- } \\
\text { tal } \\
\text { inwoners }\end{array}$ & $\begin{array}{l}\text { Gemid- } \\
\text { deld } \\
\text { opper- } \\
\text { vlak } \\
\left(\mathbf{k m}^{2}\right)\end{array}$ \\
\hline Croatië & 4.154 .213 & 76 & 87 & 47.750 & 651 \\
\hline lerland & 4.673 .700 & 72 & 92 & 50.801 & 759 \\
\hline $\begin{array}{l}\text { Noorwe- } \\
\text { gen }\end{array}$ & 5.258 .317 & 16 & 64 & 82.161 & 5.059 \\
\hline Slowakije & 5.435 .343 & 111 & 54 & 100.655 & 908 \\
\hline Finland & 5.503 .297 & 16 & 27 & 203.826 & 12.476 \\
\hline $\begin{array}{l}\text { Denemar- } \\
\text { ken }\end{array}$ & 5.748 .769 & 130 & 24 & 239.532 & 1.796 \\
\hline Servië & 7.040 .272 & 92 & 83 & 84.823 & 933 \\
\hline Bulgarije & 7.101 .859 & 64 & 113 & 62.848 & 981 \\
\hline $\begin{array}{l}\text { Zwitser- } \\
\text { land }\end{array}$ & 8.419 .550 & 200 & 108 & 77.959 & 382 \\
\hline Israël & 8.630 .000 & 376 & 32 & 269.688 & 690 \\
\hline Oostenrijk & 8.739 .806 & 104 & 115 & 75.998 & 729 \\
\hline Hongarije & 9.797 .561 & 106 & 111 & 88.266 & 838 \\
\hline Zweden & 9.995 .153 & 22 & 48 & 208.232 & 9.381 \\
\hline Tsjechië & 10.578 .820 & 135 & 86 & 123.010 & 917 \\
\hline $\begin{array}{l}\text { Grieken- } \\
\text { land }\end{array}$ & 10.783 .748 & 82 & 155 & 69.573 & 851 \\
\hline België & 11.322 .088 & 376 & 208 & 54.433 & 147 \\
\hline Nederland & 17.081 .507 & 411 & 31 & 551.016 & 1.340 \\
\hline Roemenië & 19.638.309 & 90 & 176 & 111.581 & 1.354 \\
\hline Marokko & 34.852 .121 & 76 & 248 & 140.533 & 1.801 \\
\hline Polen & 38.433 .000 & 123 & 318 & 120.858 & 981 \\
\hline $\begin{array}{l}\text { Engeland/ } \\
\text { Wales }\end{array}$ & 58.381 .300 & 267 & 235 & 248.431 & 1.032 \\
\hline Italië & 60.589 .445 & 206 & 370 & 163.755 & 814 \\
\hline Frankrijk & 66.991 .000 & 104 & 307 & 218.212 & 2.097 \\
\hline Duitsland & 82.175 .684 & 226 & 646 & 127.207 & 553 \\
\hline
\end{tabular}

Gesorteerd op omvang bevolking.

Bron: CEPEJ-rapport 2018.

De primaire gegevensbron voor de vergelijking is het tweejaarlijkse rapport van de European Commission for the Efficiency of Justice (CEPEJ) van de Raad voor Europa. Dat rapport vergelijkt de rechtsple- 
ging in 46 lidstaten van de Raad voor de Europa. In de meest recente editie (2018) hebben ook twee niet-lidstaten meegedaan: Israël en Marokko. Voor dit artikel gebruik ik gegevens van 31 landen. Het tellen en vergelijken van de schaalgrootte van de rechtspraak is complexer dan je wellicht zou verwachten. Sommige landen hebben, anders dan Nederland, stelsels met gespecialiseerde rechtbanken zoals labour courts, family courts en commercial courts. En tel je rechtbanken als 'organisatorische eenheden' of tel je het aantal geografische plaatsen waar zittingen plaatsvinden? Voor de hier te maken vergelijking gebruik ik de gegevens over het aantal rechtbanklocaties waar 'small claims' (civiel) worden behandeld. Dan heb je in Nederland de zittingsplaatsen van de kantonrechter te pakken en in België die van de vrederechter. Het zijn tevens de meest voorkomende rechtszaken, waarvoor je ook in andere landen het meest fijnmazige stelsel aantreft. De gebruikte gegevens zijn opgenomen in tabel 1 hierboven.

Figuur 1 visualiseert de schaalgrootte van de rechtspraak in een aantal Europese landen naar het gemiddeld aantal inwoners van het verzorgingsgebied van eerstelijns rechtspraakvoorziening die 'small claims' behandelt. Voor Nederland zijn dat de zittingslocaties van de kantonrechter, voor België die van de vrederechter. Het blijken uitersten. De schaalgrootte van de Nederlandse rechtspraak is extreem groot in vergelijking met de rest van Europa: een factor 2 groter dan de nummer 2, Engeland, en een factor 10 groter dan het Belgische systeem.

Figuur 2 visualiseert de schaalgrootte van de rechtspraak geografisch. Het gemiddelde oppervlak van een eerstelijns rechtspraakvoorziening is voor deze vergelijking omgerekend naar een vierkant. In deze visualisering zit Nederland in de middenmoot. België is opnieuw extreem kleinschalig. Het minst fijnmazig is de rechtspraak in de Baltische Staten en Scandinavië. Dit zijn tevens de landen met de laagste bevolkingsdichtheid. Nederland en België zijn de landen met de hoogste bevolkingsdichtheid. Er bestaat, bij de 31 landen in onze vergelijking, een statistisch significant verband tussen de bevolkingsdichtheid en de gemiddelde oppervlakte van het verzorgingsgebied van een rechtspraaklocatie ( $\left.\mathrm{r}=-0,39^{*}\right)$ : hoe groter de bevolkingsdichtheid, des te kleiner de gemiddelde oppervlakte van het verzorgingsgebied van een rechtspraaklocatie. De Nederlandse rechtspraak valt daarbij uit de toon: het meest dichtbevolkte land, maar één van de minder fijnmazige systemen. 
Figuur 1 Inwoners (gemiddeld) van het verzorgingsgebied van één rechtspraaklocatie ('small claims')

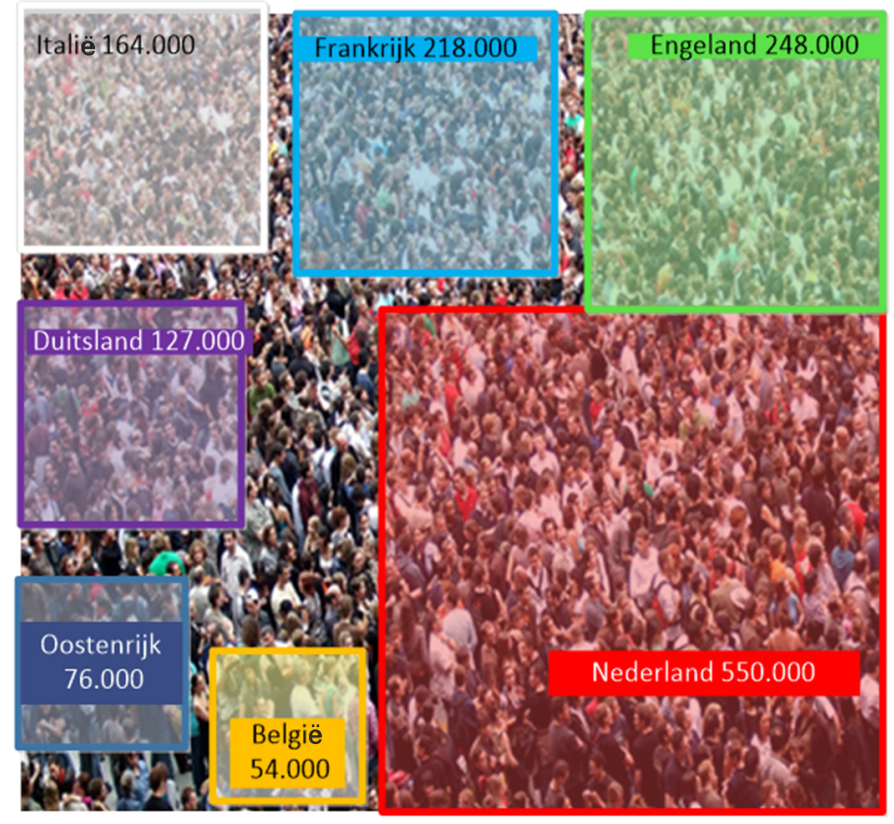

Op de eenvoudige vergelijkingen van schaalgrootte, aan de hand van de figuren 1 en 2, valt natuurlijk wel wat af te dingen. De voorstelling van de oppervlakte als een vierkant doet weinig recht aan de werkelijkheid, en geeft slechts een grove indicatie voor de verschillen in reisafstanden naar rechtspraaklocaties. Een treffend voorbeeld dicht bij huis is het arrondissement Limburg: beperkt in oppervlakte, maar zo langgerekt dat toch aanzienlijke reisafstanden ontstaan. Daarbij ligt de arrondissementsrechtsbank dan ook nog zeer excentrisch, in het zuiden van Maastricht. Andere factoren die de werkelijke reisafstanden en -tijden aanmerkelijk kunnen vergroten zijn natuurlijke barrières, zoals bergketens of water. Desalniettemin levert de vergelijking een goede eerste plaatsbepaling op voor de schaal van de rechtspraak in Nederland en België. De landen zijn vergelijkbaar qua bevolkingsdichtheid, maar uitersten als het gaat om de geografische inrichting van de rechtspraak. Het Belgische systeem kent de vrederechter in 


\section{Figuur 2 Oppervlakte (gemiddeld) van het verzorgingsgebied} van één rechtspraaklocatie

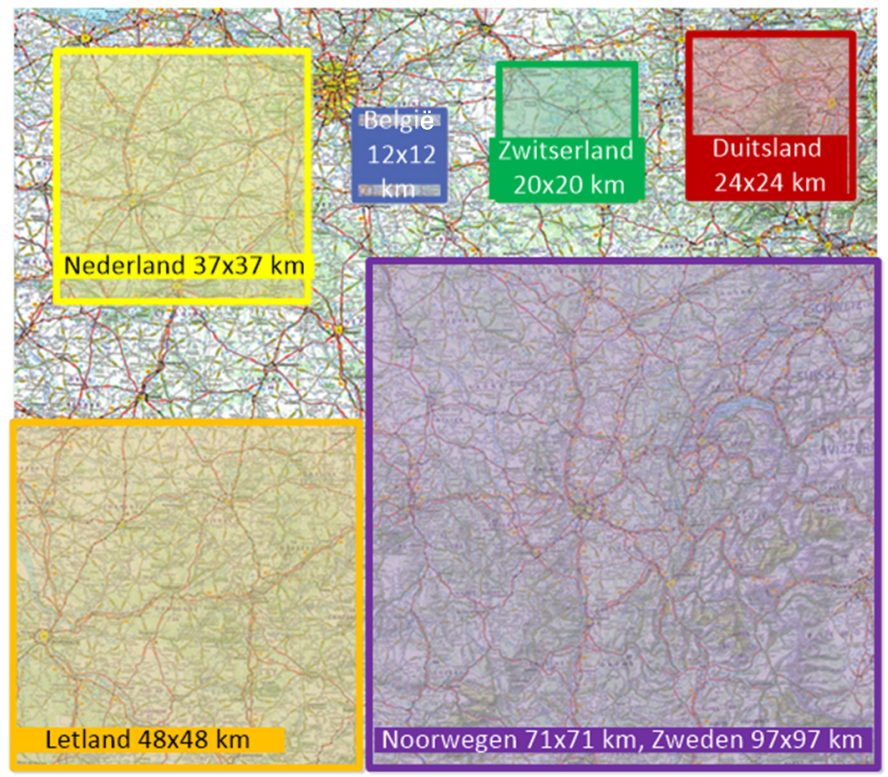

haar oervorm, met een eerstelijns rechtspraakvoorziening in vrijwel elke gemeente (of wijk, in geval van een grote stad). In andere landen met vrederechters, of een andere 'community based' traditie, ${ }^{1}$ treffen we een zo'n fijnmazig systeem niet (meer) aan. De ontwikkeling naar grotere verzorgingsgebieden wordt gestimuleerd door snellere vervoersmogelijkheden en, meer recent, de mogelijkheid om digitaal en/ of via videoverbindingen te communiceren. ${ }^{2}$ De opschaling van openbare voorzieningen vindt op alle terreinen in de samenleving plaats: gemeenten, scholen, zorginstellingen.

1 Denk bijvoorbeeld aan Portugal, waar tien jaar geleden nog een systeem bestond met ruim tweehonderd Comarca's als basis. John Braithwaite is een belangrijke inspiratiebron voor moderne toepassingen van community-rechtspleging, zoals in de VS (zie Verberk 2005, voor voorbeelden).

2 De technocraten worden overigens wel duidelijk gewaarschuwd door de Ombudsman om de digitale toegang en verbale weerbaarheid van burgers niet te overschatten. 


\section{Inrichtingskeuzes voor de Nederlandse rechtspraak}

Het vergelijken van de geografische spreiding maakt ook een aantal van de belangen duidelijk die samenhangen met de inrichtingskeuzes van de rechtspraak. Het Belgische systeem stelt het criterium 'dicht bij de burger' centraal. Bij de herziening van de gerechtelijke kaart in Nederland werd veel nadruk gelegd op intern organisatorische aspecten, zoals de (gevoelde) noodzaak van specialisatie. In kleine rechtbanken zou die onvoldoende gestalte krijgen, met negatieve gevolgen voor de kwaliteit van de rechtspraak. Bij de omvang van organisaties zijn zowel limieten aan de onderzijde (een minimumhoeveelheid rechters en personeel) als aan de bovenzijde (idem, maximumhoeveelheid) denkbaar. Figuur 3 visualiseert de factoren die hierbij van belang zijn. Daarvan valt bevolkingsdichtheid als onafhankelijke variabele op te vatten: de bevolkingsdichtheid in een gebied is een gegeven, en wordt niet aangepast in verband met een gewenste schaalgrootte van de rechtspraak. Bovendien heeft het verschillende consequenties wanneer men rechtspraak in een dicht- of in een dunbevolkt gebied moet inrichten. De andere vier factoren zijn onderwerp van menselijke inrichtingskeuzes. Het afbakenen van de geografische jurisdictie bepaalt de hoeveelheid inwoners die op een specifieke rechtbank zijn aangewezen, hun reistijd naar de rechtspraaklocatie en de organisatiegrootte van die rechtbank (via de hoeveelheid zaken en de personele capaciteit die nodig is om die zaken te behandelen). Als je op elk van die aspecten een gewenste bandbreedte formuleert, kun je aan de hand van een rekenmodel de ideale spreiding van rechtspraaklocaties over een land berekenen. ${ }^{3}$

\section{Herziening van de Gerechtelijke Kaart}

De huidige schaalgrootte van de Nederlandse rechtspraak werd bepaald bij de Herziening van de Gerechtelijke Kaart (HGK) in 2013. De besluitvorming ligt dus nog vers in het geheugen, evenals de criteria die aan bepaalde keuzes ten grondslag lagen. In de besluitvorming over de organisatie en inbedding van Rechtspraak in de afgelopen twintig jaar zijn twee commissies zeer bepalend geweest: de

3 Zo'n model, ontwikkeld bij de herinrichting van de Portugese rechtspraak, is online te vinden: https://www.sciencedirect.com/science/article/pii/S0377221718305642 


\section{Figuur 3 Factoren die de schaalgrootte van} rechtspraakvoorzieningen bepalen
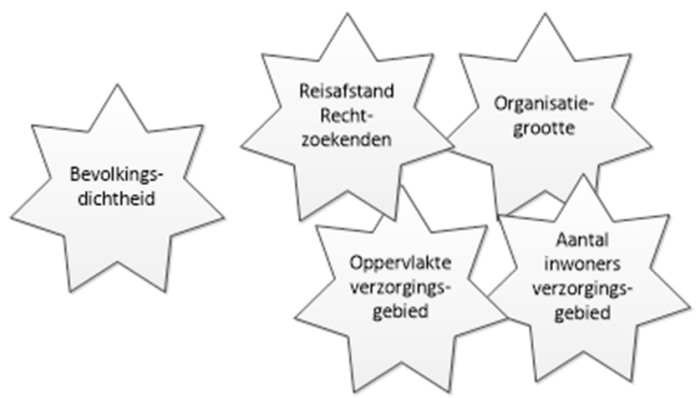

Commissie-Leemhuis (1998) en de Commissie-Deetman (2006). In de rapporten van deze commissies is geen pleidooi te vinden voor het inkrimpen van het aantal rechtspraaklocaties. De laatste commissie komt echter wel tegemoet aan de wens vanuit de Rechtspraak om zelf een 'nevenlocatiebeleid' te mogen voeren. ${ }^{4}$ De aanwijzing van rechtspraaklocaties ('nevenlocaties') moet niet meer bij wet gebeuren, maar een zaak van de Rechtspraak zelf worden. Voor de Rechtspraak geldt dan slechts de richtlijn dat voorzien moet worden in toegankelijke rechtspraak. Die zienswijze werd omarmd door de Tweede Kamer. In het kabinetsstandpunt werd daaraan toegevoegd dat de geografische organisatie van de rechtspraak moet aansluiten bij de bestuurlijke organisatie van Nederland. Daarmee waren de piketpaaltjes voor de HGK geplaatst. In het traject naar de HGK zette de Raad voor de rechtspraak in op het sluiten van veel zittingslocaties. De Raad stelde dat kwaliteitsverbetering in de Rechtspraak slechts kon worden bereikt door schaalvergroting, en wuifde bezwaren over reisafstanden of te grote organisaties weg (zie Raad voor de rechtspraak 2008). Met het oog op de onafhankelijkheid en autoriteit van de rechter pleitte men voor 'afstand' tussen de Rechtspraak en de burger: 'rechtspraak in de buurt' zou er slechts toe uitnodigen om obligate geschillen aan de rechter voor te leggen en zou het aanzien van de Rechtspraak schaden (Van den Emster e.a. 2011).

4 Aan de basis daarvan ligt het rapport van de Commissie-Van Winkel, in opdracht van de Raad voor de rechtspraak en de rechtbankpresidenten. 
De Wet HGK beoogde, aldus de Memorie van Toelichting, randvoorwaarden te creëren om de kwaliteit van de rechtspraak voor de toekomst te waarborgen. De Memorie noemt een serie fraaie doelstellingen (bevordering van de kwaliteit van het bestuur, het primaire proces en de bedrijfsvoering; bevordering van de samenwerking in de strafrechtsketen). Die zijn allemaal terug te voeren op twee ontwerpprincipes: schaalvergroting (inclusief het sluiten van kleinere locaties) en de geografische jurisdicties aanpassen aan de provinciegrenzen (aansluiten bij OM en openbaar bestuur). Het belang van die geografische congruentie geldt vooral de strafrechtsketen. De risico's met betrekking tot een te geringe schaalgrootte betreffen primair de bestuursrechtspraak (te weinig zaken per locatie om voldoende specialisme op te bouwen).

Welbeschouwd hadden de argumenten en overwegingen vooral betrekking op de arrondissementsrechtbanken, maar zouden zij niet noodzakelijk van invloed hoeven te zijn op het aantal locaties voor kantonrechtspraak. Toch werd het aantal zittingslocaties voor kantonrechtspraak drastisch ingekrompen. De behandeling in de Tweede Kamer van de Wet HGK leidde tot één majeure aanpassing in de voorgestelde indeling: het aanvankelijk voorgestelde arrondissement Oost-Nederland werd in de Tweede Kamer bestempeld als 'doorgeslagen schaalvergroting'; uiteindelijk kwamen er in dat gebied twee arrondissementen: Gelderland en Overijssel.

De herziening van de gerechtelijke kaart is geëvalueerd door de Commissie-Kummeling. Vijf jaar na de HGK concludeert de Commissie dat één van de vier doelstellingen is gerealiseerd: de kwaliteit van de bedrijfsvoering is verbeterd. In de bestuursrechtspraak zijn er 'eerste tekenen' dat de schaalvergroting bijdraagt aan het ontwikkelen van deskundigheid en specialisatie. In de andere rechtsgebieden, en ten aanzien van de andere doelstellingen, ziet men geen structurele verbeteringen. Ook uit de financiële kengetallen blijkt geen schaalvoordeel.

De commissie heeft verrast geconstateerd dat er zittingsplaatsen zijn die vrijwel niet gebruikt worden, zonder dat daar discussie over wordt gevoerd. Kennelijk is de richtlijn dat het nevenlocatiebeleid moet voorzien in toegankelijke rechtspraak er één waarin gerechtsbesturen zelfstandig - en stilletjes - hun plan trekken. 


\section{De invloed van reistijd op het gebruik van rechtspraak}

De herziening van de gerechtelijke kaart bood een unieke gelegenheid om eens goed te kijken naar de mogelijke effecten van reisafstanden op het gebruik van rechtspraak. Rond zo'n herziening kan niet alleen worden onderzocht of er een relatie is tussen het aantal te reizen kilometers en het gebruik van rechtspraak, maar kan ook systematisch worden onderzocht of een toename van reisafstand (door het opheffen van zittingslocaties) invloed heeft op het gebruik, door het vergelijken van een quasi-experimentele groep (gebieden waar de rechtspraaklocatie verdween en de reisafstanden toenamen) en een controlegroep (gebieden waar de rechtspraaklocatie bleef en de reisafstanden gelijk bleven). In de gesprekken die de commissie bij de rechtbanken voerde, was enkele malen naar voren gebracht dat gedaagden minder vaak verweer voerden nu de reisafstand naar de rechtbank was toegenomen. Dat was een zorg die ook werd geuit door het lokaal bestuur van gemeenten waar zo'n rechtspraaklocatie verdween. Ten behoeve van de evaluatiecommissie werd een studie gedaan voor de arrondissementen Limburg en Noord-Holland (Eshuis 2017). Later werd de exercitie herhaald voor het arrondissement Noord-Nederland (Eshuis 2018).

\section{Resultaten}

De studie vond geen systematische samenhang tussen het verdwijnen van een kantongerecht en een afname van verweer van gedaagden uit dat kantongebied. In totaal omvatten de uitgevoerde studies 8 gebieden (met 39 gemeenten) waar een kantongerecht verdween en 7 gebieden (58 gemeenten) waar de afstand tot de rechtspraaklocatie niet veranderde. In de gebieden waar een kantongerecht verdween, waren er 8 gemeenten met een bovengemiddelde stijging ${ }^{5}$ van het verstekpercentage (8 uit 39). In de gebieden waar niets veranderde, waren dat er 16 (16 uit 58). In 2 (van de 8) voormalige kantongebieden is het, op basis van de cijfers, begrijpelijk dat het vermoeden van een relatie tussen (toegenomen) reisafstand en meer verstek ontstaat. Uit de studies blijkt echter dat dit geen algemeen verschijnsel is, maar te wij-

5 Tussen 2012 (vóór de HGK) en 2015 (na de HGK). Sinds 2010 is sprake van een dalende trend in het aantal rechtszaken. Daarbij vertoont ook het verstekpercentage een algemeen dalende tendens. 
ten is aan (een gewone) fluctuatie in de verstekpercentages: er zijn plekken waar het verstekpercentage stijgt, en er zijn er waar het percentage daalt. Er is één voormalig kantongebied waar het verstekpercentage écht indrukkend toenam. Dat is Assen, waar de zittingslocatie gewoon in gebruik bleef en de reisafstand voor gedaagden niet veranderde.

In de studies is ook gekeken naar mogelijke samenhangen tussen (reis)afstand sec en het verstekpercentage: is er verschil tussen personen die dicht bij de zittingslocatie wonen en gedaagden die ver(der) moeten reizen in de mate waarin zij verweer voeren? Ook die analyse toont geen systematische relatie aan tussen de (reis)afstand en het verstekpercentage.

De studie vond wél een significant resultaat voor de mate waarin natuurlijke personen zaken aanbrengen: waar een kantongerecht uit de directe omgeving verdween, daalde het aantal zaken dat door natuurlijke personen voor de rechter werd gebracht. Het opheffen van locaties remt dus de vraag naar rechtspraak. Natuurlijke eisers zijn, vaker dan rechtspersonen, inwoners van de jurisdictie waar het geschil speelt. De waargenomen relatie geldt mogelijk breder voor lokaal gevestigde eisers (inclusief kleine bedrijfjes). Hierbij zij opgemerkt dat het gros van de zaken wordt aangebracht door landelijk opererende repeat players (rechtspersonen); de rol van lokale eisers is beperkt ${ }^{6}$ en de impact van de vraaguitval die optreedt bij verdwenen kantongerechten daarmee ook.

Samenvattend leveren de studies dus geen steun voor de geluiden dat de reisafstand zou leiden tot meer verstekken. Wél blijkt dat natuurlijke personen minder geneigd zijn zaken voor de rechter te brengen wanneer 'hun' kantonlocatie is opgeheven.

\section{Discussie}

In het voorgaande werden empirische gegevens besproken over de schaalgrootte van de rechtspraak, toegespitst op de eerstelijnsvoorzieningen voor eenvoudige civiele rechtszaken. Na de HGK, waarbij veel zittingslocaties werden opgeheven (of opheffing werd geformaliseerd),

6 Een exact percentage wordt niet gegeven. Woonplaats en/of postcode van de eisende partij worden in de regel niet genoemd in digitale zaaksgegevens op basis waarvan dit onderzoek werd verricht. 
wordt de roep om de rechtspraak weer (fysiek) dichter bij de burger te brengen hoorbaar. Enerzijds in experimenten als spreekuur- en wijkrechters, anderzijds in het initiatief om de vrederechter te revitaliseren. Ik zal op basis van het voorgaande enkele vragen en aandachtspunten formuleren met betrekking tot die ontwikkeling.

Allereerst is er de drang om kantonlocaties te sluiten. Waar die vandaan komt? De rapporten die richting gaven aan de ontwikkeling van de rechtspraak in de afgelopen twintig jaar (Leemhuis, Deetman) bevatten geen oproep om locaties te sluiten. En andere rapporten uit die periode evenmin. Integendeel. Wat we daarin wél lezen, is dat de commissies geen noodzaak zien om locaties te sluiten. Dat een afstand wordt voorgesteld van maximaal 50 kilometer die rechtzoekenden zouden moeten reizen naar hun rechtspraaklocatie. Dat rechtspraakorganisaties niet boven de $70 \mathrm{fte}$ aan rechters zouden moeten groeien. Et cetera. Maar na ‘Deetman' slaat het denken om en dringt de Rechtspraak aan op sluiten van een flink aantal nevenlocaties. ${ }^{7}$ De Raad voor de rechtspraak en de gerechtsbestuurders zijn gangmakers in de saneringsdrift. Dat blijkt niet alleen uit het buiten gebruik stellen van locaties nog voordat de HGK zou plaatsvinden; de Commissie-Kummeling signaleerde tijdens de evaluatie van de HGK dat er locaties waren die HGK hadden overleefd, maar niet meer werden gebruikt. Ook was er het meerjarenplan van de rechtspraak, kort na de HGK, dat erop aanstuurde nog meer locaties te sluiten. ${ }^{8}$ Tijdens de rechtbankbezoeken van de Commissie-Kummeling hoorde ik zelf de discussies over het gebruik van zittingslocaties zonder kantonfunctie. In de ervaring van de rechter kost het behandelen van zaken op zo'n locatie extra tijd (reizen, sjouwen met dossiers). Zijn collega's vinden het reuze lastig als de rechter niet op kantoor is. De controller vindt die reizende rechters ook maar duur, en stoort zich aan al die andere extra kosten die aan de nevenlocatie zijn verbonden (ondersteunende diensten, onderhoud, transport enzovoort). De bestuurder van de rechtbank met veel nevenlocaties is zich ervan bewust dat de nevenlocaties niet gunstig zijn voor de financiële kengetallen van zijn gerecht. In die constellatie zullen nevenlocaties slechts overleven als het gerechtsbestuur of individuele rechters zich daar écht voor willen

7 Sterker: in zijn advies over de HGK deelt de Raad mee daar al mee bezig te zijn (Raad voor de rechtspraak 2008).

8 Vlak voor het ter perse gaan van dit artikel verscheen een rapport van de Boston Consultancy Group (2019), waarin opnieuw de sluiting van rechtspraaklocaties werd voorgesteld. 
inspannen. ${ }^{9}$ Je kunt de lijn onmiddellijk doortrekken naar locatiebezoeken ('descente') tijdens gewone gerechtelijke procedures. Ook die worden als 'duur' beschouwd en weinig toegepast. ${ }^{10}$ In de kwaliteitskengetallen levert het de rechtbank ook geen bonus op als rechters een zaak op locatie behandelen. De nieuwe initiatieven waarin rechters naar de burgers toegaan (wijkrechter, burenrechter) zullen met dezelfde belemmeringen te maken krijgen. Wil zo'n aanpak beklijven, dat zal rechtspraak op locatie op één of andere wijze aantrekkelijk moeten worden gemaakt.

De meeste rechtszaken in eerste aanleg worden behandeld door de kantonrechter. Voor een doorsnee rechtzoekende is de kantonrechter het 'gezicht' van de rechtspraak. Twintig jaar geleden hielden veel van die kantonrechters zitting in een oud gebouw in het centrum van een middelgrote stad. Je kon er zonder veel poespas naar binnen lopen. De kantonrechter kende de couleur locale. Anno 2019 vindt kantonrechtspraak meestal plaats in een groot kantoorgebouw, waar een flink aantal hordes (portier, legitimatie, bagagescan, detectorpoortje, volgende portier) moet worden genomen om binnen te komen. Begrijpelijke voorzorgsmaatregelen in de huidige samenleving. Een kleine rechtspraaklocatie open houden wordt financieel steeds onaantrekkelijker. Bij het experiment met de Spreekuurrechter is men er niet in geslaagd om daadwerkelijk een laagdrempelig 'spreekuur' te realiseren. Het lijkt onvermijdelijk dat de moderne rechtspraakvoorzieningen tot meer (ervaren) 'afstand' leiden. De schaal van de Nederlandse rechtspraak na de HGK is, gemeten naar het aantal inwoners van het verzorgingsgebied van een rechtbank, extreem groot. Dat betekent dat er veel zaken moeten worden behandeld en veel personeel nodig is. De gemiddelde arrondissementsrechtbank heeft een personeelsbestand van tussen 500 en $1.000 \mathrm{fte}$. De Commissie-Deetman beoogde dat 'de wetgever de gerechten in de toekomst meer mogelijkheden en ruimte dient te bieden bij het inrichten van het bestuur, de nevenlocaties en de onderlinge samenwerking (...). Naar het oordeel van de commissie kan dit de in aard en omvang doorgeschoten overlegcultuur ombuigen, de slagkracht van de organisatie versterken en de door medewer-

9 De NVvR zag de sanering, blijkens haar advies over de Wet HGK, al ruim tevoren aankomen. De Minister reageerde destijds met de geruststellende mededeling dat de Raad voor de rechtspraak echt niet uit is op een verdere sanering.

10 In handelszaken met een financieel belang van $€ 5.000 \mathrm{t} / \mathrm{m} € 25.000$ verrichtten kantonrechters in $0,4 \%$ van de procedures op tegenspraak een descente. Het gebruik door handelsrechters was nog lager (Eshuis \& Geurts 2016). 
kers ervaren werkdruk en bureaucratie verminderen.' Het is bijna flauw om de vraag te stellen of dat is gelukt. De HGK heeft, met name bij fusiegerechten, tot een heel nieuw circuit van overleg en afstemming geleid, waarbij sommige nevenlocaties continu hun bestaansrecht lijken te moeten bevechten. De evaluatiecommissie ziet de gerechten na vijf jaar nog steeds worstelen met het vinden van 'een geschikte' organisatiestructuur. Rechters ervaren een toegenomen afstand tussen werkvloer en bestuur. Het lijkt een werkomgeving waarin externe adviseurs en interimmanagers zullen floreren. Voor rechters en medewerkers die in het primaire proces van de rechtspraak werkzaam zijn, ben ik daar minder zeker van. Uit de vergelijkingen van schaalgrootte en reisafstanden blijkt dat de reisafstanden naar rechtspraaklocaties in Nederland weliswaar groter zijn dan in aangrenzende landen, maar in Europees perspectief zeker niet extreem. Een van de uitgangspunten bij de HGK was dat de grootste steden over een eigen rechtbank moeten beschikken. Een logische keuze als je bedenkt dat daar veel mensen op een relatief korte afstand wonen, en mensen van verder weg regelmatig de stad zullen bezoeken vanwege de regiofunctie. Zodoende was er naast de vele opgeheven locaties ook een opwaardering voor Eindhoven en Almere. In krimpregio's (Zuid-Limburg, Oost-Groningen, Zeeuws-Vlaanderen, WestFriesland) zijn veel locaties opgeheven. Dat heeft ook een keerzijde. In de krimpregio's zit veel schuldenproblematiek, die tot veel rechtszaken leidt. De rechtspraak vervult ook een eigen rol in schuldsaneringstrajecten. Uit de onderzoeken naar de relatie tussen reisafstand en rechtspraak blijkt dat het gemiddeld gezinsinkomen een goede voorspeller is voor de hoeveelheid rechtszaken die tegen inwoners van een gemeente worden aangebracht. Er is veel voor te zeggen om juist in gebieden met lage inkomens rechtspraak (fysiek) dicht bij de burger aan te (blijven) bieden. Personen die hun rekeningen niet (kunnen) betalen, worden relatief vaak voor de rechter gedaagd. Tegelijk zullen reisafstanden en -kosten voor deze groep meer een barrière opwerpen dan voor andere rechtzoekenden. 


\section{Literatuur}

Boston Consultancy Group 2019 Boston Consultancy Group, Doorlichting Financiën Rechtspraak, Amsterdam 2019.

\section{CEPEJ 2018}

European Commission for the Efficiency of Justice (CEPEJ), European judicial systems 2018 (2016 data) - Efficiency and quality of justice, CEPEJ Studies No. 26, Straatsburg: CEPEJ 2018.

\section{Commissie-Deetman 2006}

Commissie evaluatie modernisering rechterlijke organisatie, Rechtspraak is Kwaliteit, Den Haag: Ministerie van Justitie 2006.

\section{Commissie-Kummeling 2017}

Commissie Evaluatie Wet herziening gerechtelijke kaart, Evaluatie Wet HGK, Den Haag: Ministerie van Justitie en Veiligheid 2017.

\section{Commissie-Leemhuis 1998}

Commissie-Leemhuis, Rechtspraak bij de Tijd. Rapport van de Adviescommissie toerusting en organisatie zittende magistratuur, Den Haag: Ministerie van Justitie 1998.

\section{Commissie-Van der Winkel 2006}

Commissie-Van der Winkel, Goede rechtspraak door sterke regio's. Eindrapport. Den Haag: Raad voor de rechtspraak 2006.

\section{Van den Emster e.a. 2011}

E. van den Emster, E. van Amelsfort \& F. van Dijk, Re-structuring of the judicial map. Quality through collaboration, Den Haag: Raad voor de rechtspraak 2011, www.rechtspraak.nl/

SiteCollectionDocuments/Restructuring-of-the-Judicial-Map. pdf

\section{Eshuis 2017}

R.J.J. Eshuis, De rechter op afstand. Een verkennend onderzoek naar de relatie tussen reisafstand en het gebruik van rechtspraak, Den Haag: WODC, Memorandum 2017-05.

\section{Eshuis 2018}

R.J.J. Eshuis, Reistijd en gebruik van Rechtspraak in Noord-Nederland, Den Haag: WODC, Memorandum 2018-03.

\section{Eshuis \& Geurts 2016}

R.J.J. Eshuis \& T. Geurts, Lagere drempels voor rechtzoekenden. Evaluatie van de Verhoging van de Competentiegrens in 2011, Den Haag: WODC, Cahier 2016-14.

\section{Klein Haarhuis 2005}

C. Klein Haarhuis, Naar een conceptueel kader voor de spreiding van rechtspraak, Een verkenning aan de hand van inzichten van onderwijs en zorg, Den Haag: WODC/Ministerie van Justitie 2005. 


\section{NVvR 2011}

Nederlandse Vereniging voor Rechtspraak, Advies Gerechtelijke kaart II, 2001, www. officielebekendmakingen.nl/blg -131884.pdf

\section{Struiksma e.a. 2000}

N. Struiksma, A.J.E. Edzes, H.B.Winter, M. Herweijer e.a., Situeren met beleid. Een onderzoek naar het nevenlocatiebeleid van rechtbanken, Groningen:

RUG 2000.

\section{Teixeira e.a. 2019}

J.C. Teixeira, J.F. Bigotte, H.M. Repolho \& A.P. Antunes, 'Location of courts of justice: The making of the new judiciary map of Portugal', European Journal of Operational Research (272) 2019, afl. 2, p. 608-620.

\section{Verberk 2005}

S. Verberk, Rechter onder de mensen? Over de externe oriëntatie van de rechterlijke macht in Californië, Den Haag: Raad voor de rechtspraak, Research Memoranda nr. 3-2005.

\section{Werkgroep BOK 2006}

Werkgroep Bestuurlijke Onderbrenging Kanton, Kantonrechtspraak in de 2le eeuw. Naar afdoening 'op maat'. Een bijdrage aan de evaluatie van de bestuurlijke onderbrenging van de kantongerechten, Den Haag: Kring van Kantonrechters en het Landelijk Overleg van Kantonsectorvoorzitters 2006. 